\title{
Z gabinetu osobliwości do gabinetu naturalnego, od kultury ciekawości do fascynacji nauką, czyli Józefa Jerzego Hylzena wkraczanie w świat uczonych
}

\author{
From the Cabinet of Curiosities to the Physical Cabinet, \\ from the Culture of Curiosity to the Fascination with \\ Science, or Józef Jerzy Hylzen Enters the Scholarly World
}

The article discusses the educational journey Józef Jerzy Hylzen embarked upon between 1752 and 1754 , paying special attention to the interest of the peregrinator in natural sciences. A noticeable change took place in the approach to the things he saw; collections of curiosities were slowly being replaced by physical cabinets of 18th-century scholars. Thanks to participation in Jean-Antoine Nollet's demonstrations of experimental physics, young Hylzen gained a new curiosity of the world. Nollet gave him the opportunity to meet other naturalists from France and the Netherlands: René Antoine Ferchault de Réaumur, Pieter van Musschenbroek and Jean-Nicolas-Sébastien Allamand. Hylzen visited their physical cabinets which no longer reflected collector's passion as they became places of scholarly study. Dividing the collected items by genre made them into prototypes of today's museums, as scholars would often pass their collections to them.

Keywords: education, Grand Tour, cabinet of curiosities (cabinet of wonder), physical cabinet, Józef Jerzy Hylzen, Jean-Antoine Nollet, experimental physics, 18th century

Słowa kluczowe: edukacja, Grand Tour, gabinet osobliwości, gabinet naturalny, Józef Jerzy Hylzen, Jean-Antoine Nollet, fizyka eksperymentalna, XVIII wiek

Młodzież z terenów Rzeczypospolitej Obojga Narodów często podejmowała zagraniczne podróże edukacyjne. Moda na nie pojawiła się w dobie późnego średniowiecza i epoce renesansu, gdy coraz popularniejsze stawały się wyjazdy akademickie (peregrinatio 
academica) na określone uniwersytety, chociażby niemieckie'. W XVII stuleciu pojawiło się zjawisko „wielkiej podróży” (Grand Tour), które zmieniło dotychczasową edukację. Peregrynacja „do cudzych krajów”, po niemalże całej Europie Zachodniej, „po wiedzę i doświadczenie" stawała się także coraz częstsza wśród zamożnej szlachty polsko-litewskiej. Twierdzono, że klasyczne studia uniwersyteckie nie uczą życia. Aby „wielka podróż” przyniosła jak najwięcej korzyści, w instrukcjach rodzicielskich² przekazywano rady, jak ma ona wyglądać, dokąd miano się udać, czego w jej trakcie miano się uczyć - zarówno jeśli chodzi o szkolne przedmioty, jak i „praktyki życiowe”. Wśród ojcowskich zaleceń pojawiały się konkretne państwa, które należało odwiedzić: Italia na czele z Wiecznym Miastem, Francja z Wersalem jako wzorem dworskiej etykiety, z czasem zaczęto wymieniać Wiedeń, Niderlandy, ziemie niemieckie, Półwysep Iberyjski, Hiszpanię, Anglię, Szwajcarię. To tam miano w praktyce wykorzystywać wiedzę pozyskaną w kolegiach zakonnych, obcować ze sztuką, kulturą, zawierać znajomości, bywać wśród wielkich tego świata, uczyć się języków obcych oraz etykiety ${ }^{3}$. Podczas „wielkiej podróży” rezygnowano z pełnego cyklu studiów w danej akademii, czasem wybierano konkretny przedmiot lub w ogóle odrzucano instytucjonalną edukację na rzecz prywatnych lekcji geografii, historii, łaciny, prawa, nowożytnych języków obcych, ćwiczeń rycerskich i wojskowych, gry na instrumencie, tańca. Wreszcie tura kawalerska miała potwierdzić prestiż własny, rodu, a jednocześnie być podstawą przyszłej kariery urzędniczej peregrynanta ${ }^{4}$. W drugiej połowie XVII w. zagraniczne podróże edukacyjne były już niezwykle popularne, wręcz obowiązkowe, wśród niektórych rodów magnackich, chociażby Sobieskich ${ }^{5}$, Jabłonowskich ${ }^{6}$, Lubomirskich ${ }^{7}$, Potockich, Czartoryskich, Sapiehów, Radziwiłłów ${ }^{8}$, Zamoyskich ${ }^{9}$ czy Rzewuskich ${ }^{10}$.

W wielu instrukcjach rodzicielskich oraz w tekstach apodemicznych na temat edukacyjnych peregrynacji staropolskich pojawiały się zalecenia „rzeczy”, które w czasie podróży należało obejrzeć. Skutkiem tego w powstających na gorąco relacjach z wojaży do standardowych opisów dotyczących wielkości miasta, jego cech obronnych, obwarowań,

1 D. Żołądź-Strzelczyk, Peregrinatio academica. Studia młodzieży polskiej z Korony i Litwy na akademiach i uniwersytetach niemieckich w XVI i pierwszej połowie XVII wieku, Poznań 1996.

2 Ostatnio ukazały się liczne edycje instrukcji rodzicielskich zawarte w: Ojcowskie synom przestrogi. Instrukcje rodzicielskie (XVI-XVII w.), oprac. D. Żołądź-Strzelczyk, M.E. Kowalczyk, Wrocław 2017; Przestrogi i nauki dla dzieci. Instrukcje rodzicielskie (XVIII w.), oprac. D. Żołądź-Strzelczyk, M.E. Kowalczyk, Wrocław 2017.

3 A. Mączak, Turystyka europejska. Wieki XVI-XIX, „Folia Turistica” 2008, nr 19, s. 8-9; M. Bratuń, Z dziejów europejskiego "Grand Tour” w XVII i XVIII wieku, „Kwartalnik Opolski” t. 49, 2003, z. 1, s. 7-12.

4 M. Bratuń, Grand Tour. Narodziny - rozwój - zmierzch, [w:] Polski Grand Tour w XVIII i początkach XIX wieku, red. A. Roćko, Warszawa 2014, s. 21-22; A. Mączak, Odkrywanie Europy. Podróże w czasach renesansu i baroku, Gdańsk 1998, s. 7.

5 J. Sobieski, Peregrynacja po Europie (1607-1613). Droga do Baden (1638), oprac. J. Długosz, Wrocław 1990; S. Gawarecki, Diariusz drogi. Podróż Jana i Marka Sobieskich po Europie 1646-1648, oprac. M. Kunicki-Goldfinger, Warszawa 2013; K. Targosz, Jana Sobieskiego nauki i peregrynacje, Wrocław 1985.

6 A. Markiewicz, Podróże edukacyjne w czasach Jana III Sobieskiego. Peregrinationes Jablonovianae, Warszawa 2011.

7 D. Żołądź-Strzelczyk, Edukacja Lubomirskich w drugiej połowie XVI i XVII wieku, [w:] eadem, „Pod każdym względem szlachetne ci daję wychowanie...". Studia z dziejów wychowania szlachty w epoce staropolskiej, Wrocław 2017, s. 21-49.

8 M. Chachaj, Zagraniczna edukacja Radziwiłtów od początku XVI do połowy XVII wieku, Lublin 1995.

9 A. Kucharski, Grand Tour Tomasza, Michała i Marcina Zamoyskich z przełomu XVII i XVIII wieku, "Klio” t. 33, 2015, nr 2, s. 73-101.

10 A. Kucharski, S. Roszak, A. Wieczorek, O podróżach edukacyjnych w XVII i XVIII wieku - przypadek Rzewuskich, [w:] Społeczne i kulturowe uwarunkowania edukacji Rzeczypospolitej XVI-XVIII wieku. Materiały z badań, część pierwsza, red. K. Puchowski, oprac. J. Orzeł, Warszawa 2017, s. 75-97. 
architektury, zwłaszcza sakralnej, panującej w danym państwie religii, obyczajów i stosunków społecznych dodawano „miejsca godne widzenia”. Najczęściej były to siedziby rodów panujących, galerie obrazów, zbiory wotów. W epoce baroku coraz częściej zalecano zwiedzać kolekcje znajdujące się w "gabinetach naturalnych", nazywanych czasem także "gabinetami osobliwości"11. Te ostatnie odnosiły się do kultury ciekawości, która w XVIII w. była skupiona nie tylko na tym, co warto zobaczyć, co było polecane w przewodnikach czy instrukcjach rodzicielskich, lecz przede wszystkim na zobaczeniu czegoś nowego, czegoś, czym można było się pochwalić po powrocie do ojczyzny.

Kultura ciekawości wiązała się z chęcią zobaczenia „osobliwych przedmiotów"12 zdeponowanych w jednym miejscu, lecz także z poznaniem osoby-kolekcjonera. Z jednej strony była to postać, która chciała się dowiedzieć o świecie czegoś nowego, posiadać niezwykłe, nieoczywiste przedmioty, z drugiej strony kolekcjoner ze zbieractwa czerpał swoistą przyjemność ${ }^{3}$. Niepowtarzalność zebranych przez niego obiektów nie zawsze była widoczna na pierwszy rzut oka, czasem w ogóle nie była dostrzegana w wyglądzie dopiero w opowieści na ich temat ${ }^{14}$, stąd tak ważna rola ich właściciela czy przewodnika, który z pasją omawiał i pokazywał swoje skarby.

Kolekcje takie można uznać za prototyp muzeum ${ }^{15}$ - jeszcze nieskonkretyzowany, niestematyzowany. W XVIII w. „kolekcje muzealne były tak powszechne i popularne, iż nie było właściwie większego miasta (zwłaszcza uniwersyteckiego) czy rezydencji monarszej, w których nie znajdowałoby się musaeum, Kunstkammera czy gabinet osobliwości"16. Znajdowały się w nich kolekcje przedmiotów odzwierciedlających aktualny stan wiedzy, co potem wykorzystali twórcy Encyklopedii ${ }^{17}$. Oprócz tradycyjnych skarbnic wiedzy, czyli książek, gromadzono wyroby sztuki (obrazy, ryciny, rzeźby, monety, dzieła sztuki zdobniczej) i coraz częściej przedmioty związane z naukami przyrodniczymi, zatem instrumenty i narzędzia naukowe. W 1698 r. w szkole w Halle jej twórca, August Hermann Francke, stworzył gabinet osobliwości zwany Naturalienkammer des Halleschen Waisenhauses. Uznawał bowiem, że jest to niezbędny element nowoczesnego kształcenia młodzieży ${ }^{18}$.

11 O zawiłościach terminologicznych pojęć cabinet, kammera, studiolo odnoszących się do gabinetów osobliwości zob. J. Czerzniewska, Cabinet, kammera, studiolo. Konstrukcja wiedzy o niezwykłych przedmiotach i sztuce, [w:] Curiosità - zjawiska osobliwe w sztuce, literaturze i obyczaju, red. A.S. Czyż, J. Nowiński, Warszawa 2013, s. 27-37, tam dalsza literatura.

12 Analizę pojęć curieux i curiosité przeprowadzili: K. Pomian, Zbieracze i osobliwości. Paryż-Wenecja XVI-XVIII wiek, tłum. A. Pieńkos, Gdańsk 2012, s. 75-78; M. Mencfel, Osobliwy, czyli jaki? Kategoria niezwykłości w kulturze naukowej, artystycznej i kolekcjonerskiej epoki nowożytnej, [w:] Curiosità, op. cit., s. 11. Por. także wcześniejszą pracę tego autora: Skarbce natury i sztuki. Prywatne gabinety osobliwości, kolekcje sztuki i naturaliów na Śląsku w wieku XVII i XVIII, Warszawa 2010, s. 7-9.

13 K. Pomian, op. cit., s. 19-20.

14 M. Mencfel, Osobliwy, czyli jaki?, s. 22.

15 Szerzej zob. M.P. Markowski, Anatomia ciekawości, Kraków 1999, s. 12.

16 D. Folga-Januszewska, Muzeum: fenomeny i problemy, Kraków 2015, s. 7. Zob. szerzej: D. Poulot, Musée et muséologie, Paris 2009, s. 6-21. O kulturze ciekawości, gabinetach osobliwości jako prototypach muzeów szerzej zob. liczne artykuły z różnymi przykładami z terenu Europy oraz Rzeczypospolitej Obojga Narodów w epoce renesansu i baroku w: The Origins of Museums. The Cabinet of Curiosities in Sixteenth- and SeventeenthCentury Europe, red. O. Impey, A. MacGregor, Oxford 1985, passim; Collection, Laboratory, Theater: Scenes of Knowledge in the $17^{\text {th }}$ Century, red. H. Schramm, L. Schwarte, J. Lazardzig, Berlin, New York 2005, passim; oraz w pracach: A. Kucharski, op. cit. s. 345-424; M. Mencfel, Skarbce natury, passim.

17 D. Folga-Januszewska, op. cit., s. 7.

18 T. Müller-Bahlke, Die Wunder Kammer der Frankeschen Stiftungen, Halle 2003, cyt. za: D. Folga-Januszewska, op. cit., s. 32 . 
Powstał on obok biblioteki gromadzącej ok. 18000 tomów, jednej z najbardziej znaczących tego czasu ${ }^{19}$. W gabinecie tym zachowany był układ, w którym odbiorca mógł ujrzeć „historię stworzenia od minerałów, skamieniałości, okazów botanicznych i zoologicznych, przez pierwsze dzieła człowieka (etnografia), po pierwsze dzieła cywilizacji kultury (języki, alfabety, pisma), narzędzia, instrumenty, w tym astronomiczne, po przykłady sztuk pięknych, druków, rycin i wszelkich wytworów ludzkiej działalności"20. Związane z instytucją lub z miastem osoby, podróżnicy, misjonarze peregrynujący po całym świecie zdobywali i następnie przekazywali Franckemu cenne obiekty do gabinetu. W latach dwudziestych XVIII w. kolekcja dydaktyczna zmieniła się w muzealną, liczącą 3000 obiektów, odwiedzaną przez około 60 osób dziennie ${ }^{21}$.

To tylko jeden z przykładów, w jaki sposób obok akademii i biblioteki gabinet naturalny, gabinet osobliwości stał się nowym typem instytucji, nie tylko naukowej, dziś powiedzielibyśmy, także popularyzatorskiej. Instytucje te były chętnie odwiedzane przez podróżników z Rzeczypospolitej Obojga Narodów, czego dowody znajdujemy w pozostawionych przez nich relacjach ${ }^{22}$. Polska literatura przedmiotu wciąż mało miejsca poświęca nauce i jej miejscu w wojażach XVIII w. ${ }^{23}$ Z zapisów pozostawionych przez peregrynantów $z$ ich podróży edukacyjnych wynika, że kolekcje takie zwiedzali. Dziennik z Grand Tour nastoletniego Józefa Jerzego Hylzena z lat 1752-1754 jest źródłem w tym wypadku niezwykle interesującym - nie tylko w kwestii opisu gabinetów osobliwości, lecz także dzięki stosunkowi podróżnika do nauk przyrodniczych i jego dociekliwości w kwestiach technicznych. Młodzieniec ten w trakcie swojej dwuletniej tury szczególną uwagę zwracał na wszelkiego typu maszyny i ich konstrukcję. W dzienniku z podróży zapisywał, jak funkcjonują systemy kanalizacji, pompy wodne, fontanny. W czasie peregrynacji jego zainteresowanie naukami ścisłymi, używając współczesnej terminologii, przybierało na sile.

Zainteresowanie naukami przyrodniczymi Józefa Jerzego ujawniło się w wiedeńskim Collegium Theresianum - pierwszym miejscu jego edukacyjnej podróży. To tutaj młody szlachcic podziwiał doświadczenia fizyczne wykonywane przez nauczyciela i skrupulatnie je zapisał:

$1^{\circ}$ cubulus na przykład aeneus będąc, in aequilibrio, cum cubulo ferreo pomoczony, aequilibrium tracą. $2^{\circ}$ woda na przykład przez coni basim z impetem ciecząca per motum aeris przy końcu ze ś[r]zodka in gyrum agit. $3^{\circ}$ chcąc wiedzieć,

19 F. Lippold, Gabinety osobliwości i edukacja w państwach niemieckich w XVII i XVIII wieku na przykładzie kunstkamery Augusta Hermanna Franckego w Halle, [w:] Johann Joachim Winckelmann i Stanisław Kostka Potocki. Mistrzowie i uczniowie. Materiały międzynarodowej konferencji zorganizowanej w Muzeum Pałacu Króla Jana III w Wilanowie, Warszawa 8-9 maja 2014 r. T. 1, Nowe badania i dokumenty / Johann Joachim Winckelmann und Stanisław Kostka Potocki. Meister und Schüler. Akten des internationalen Kongresses im Museum Palast König Johann III. in Wilanów, Warschau 8.-9. Mai 2014. Bd. 1, Neue Forschungen und Dokumente, red. P. Jaskanis, M. Kunze, Mainz, Ruhpolding, Warszawa 2016, s. 20.

20 D. Folga-Januszewska, op. cit., s. 32.

21 F. Lippold, op. cit., s. 20.

22 O podróżach tego czasu por. m.in. H. Dziechcińska, O staropolskich dziennikach podróży, Warszawa 1991; eadem, „Podróż” w druku i rękopisie, [w:] Staropolska kultura rękopisu, red. H. Dziechcińska, Warszawa 1990; B. Rok, Zagraniczne podróże Polaków w pierwszej połowie XVIII W., „Śląski Kwartalnik Historyczny 'Sobótka”" t. 47, 1992, z. 1-2, s. 171-178; A. Kucharski, Theatrum peregrinandi. Poznawcze aspekty staropolskich podróży w epoce późnego baroku, Toruń 2013.

23 Inaczej ta sytuacja wygląda np. w niemieckiej literaturze, por. U. Kutter, Reisen - Handbücher - Wissenschaft. Materialien zur Reisekultur im 18. Jahrhundert, Neuried 1996. 
jaka jest głębokość wody, powiesić potrzeba wolno corpus leve ad grave, potem włożyć przódy corpus grave do wody, a potem leve; na dnie leve zostawi grave i na wierzchu się pokaże. Chcąc zatem wiedzieć głębokość liquidi, wiedząc wiele in una za się bawi, łatwo dociec można24.

W okresie kilkumiesięcznej wiedeńskiej edukacji Hylzen podał zaledwie jeden przykład takich zajęć. Przykuły one jednak uwagę młodzieńca, skoro dokładnie opisał eksperymenty, a o innych lekcjach tylko wspominał, że się odbyły.

Będąc w Wiedniu, młody Hylzen odnotował także informację o gabinecie naturalnym Johanna Rittera von Baillou (1684-1758). Zapiska znalazła się w opisie miejsc, które w stolicy Cesarstwa należało zobaczyć:

Miejsca w Wiedniu, które byłoby cudzoziemcowi widzieć należy, są: skarb cesarski, ogrody przedniejsze na przedmieściu i pałace, arsenał mie[j]ski, arsenał cesarski, groby cesarzów u oo. augustynów, biblioteka cesarska, kościół ś[więtego] Karola Boromeusza, bildgaleria cesarska, a najbardziej JMP Ballu [?] gabinet naturalny ${ }^{25}$.

Johann Ritter von Baillou po studiach matematycznych i przyrodniczych znalazł się w Italii, gdzie był m.in. dyrektorem Galerii Uffizi. Jednak Baillou to nie tylko miłośnik nauk, lecz przede wszystkim kolekcjoner, właściciel około 30000 eksponatów (skamielin, muszli, korali, minerałów, kamieni szlachetnych), które dały początek najpierw cesarskiemu gabinetowi naturalnemu, a następnie stworzonemu w 1750 r. Muzeum Historii Naturalnej (Naturhistorisches Museum) w Wiedniu². Johann Ritter von Baillou był pierwszym dyrektorem tej instytucji. Na Hylzenie eksponaty kolekcjonera najwidoczniej nie zrobiły wrażenia albo nie udało mu się zwiedzić muzeum. Ta ostatnia sytuacja tym bardziej by dziwiła, gdyż peregrynant spędził w Wiedniu niemalże osiem miesięcy (od 9 października 1752 r. do 30 maja 1753 r.). Gdyby jednak zobaczył gabinet naturalny Baillou, z pewnością by go opisał lub chociaż wspomniał o pobycie w nim.

Następnym przystankiem tury kawalerskiej Hylzena była Bawaria, gdzie odwiedził siedzibę Wittelsbachów. Opis ich pałacu w Schleisscheim jest potwierdzeniem zainteresowań naukami przyrodniczymi. W tamtejszym ogrodzie zafascynowała go łaźnia „i pokoiki, do tejże łaźni należące windy, skąd woda lub gorąca, lub zimna do wanny przychodzi"27. Z kolei w samym Monachium Hylzen podziwiał „wielką pompę, skąd na potrzebę miasta wychodzi woda. Windy motu rotarum za zniżaniem się wodą napełniają się, a za zwyżeniem się na górę wyrzucają"28. Podobne wrażenia wywołało na nim odwiedzone później Blamont, gdzie znajdował się wielki kanał,

24 Juozapo Jurgio Hilzeno 1752-1754 metu kelionés dienoraštis / Dziennik podróży Józefa Jerzego Hylzena z lat 1752-1754, red. A. Pacevičius, oprac. J. Orzeł, A. Pacevičius, S. Roszak, Vilnius 2013, s. 135.

25 Ibid., s. 134.

26 C. von Wurzbach, Baillou, Johann chevalier, [w:] Biographisches Lexikon des Kaiserthums Oesterreich, cz. 14, Wien 1865, s. 388-390. Szerzej zob. Ch. Riedl-Dorn, Chevalier de Baillou und das Naturalienkabinett, [w:] Lothringens Erbe. Franz Stephan von Lothringen (1708-1765) und sein Wirken in Wirtschaft, Wissenschaft und Kunst der Habsburgermonarchie, red. R. Zedinger, St. Pölten 2000, s. 111-115.

27 Juozapo Jurgio Hilzeno 1752-1754, s. 151.

28 Ibid., s. 153. 
do którego rurami jest sprowadzona woda, na której młyn barzo sztucznie zrobiony z inszymi około statuami. Ma komunikację taką, że woda według osoby wygrywa, to jest, że kur, wół, ptaki śpiewają. Żołnierze, mularze i inni robotnicy swoją funkcję czynią. Takich figur różnych jest około stu ${ }^{29}$.

Najdłuższym przystankiem w podróży edukacyjnej Józefa Jerzego Hylzena była stolica Francji. W niej odwiedził powstałe w latach 1667-1671 Obserwatorium Paryskie, dzięki któremu - jak zaznaczył - oglądano gwiazdy i planety. Parę dni później chciał ze swoim guwernerem, księdzem Karolem Wyrwiczem, kupić mikroskop i urządzenie optyczne, zwane perspektywą ${ }^{30}$, co potwierdza jego zainteresowania oraz chęć samodzielnego prowadzenia eksperymentów.

W przeciwieństwie do Wiednia, gdzie Hylzen pobierał nauki w kolegium jezuickim, w Paryżu nie uczęszczał do konkretnej akademii - pobierał lekcje prywatne lub chodził na zajęcia do różnych profesorów. Jednym z nich był opat Jean-Antoine Nollet (17001770) ${ }^{31}$. W latach trzydziestych XVIII w. prowadził on badania dotyczące fizyki eksperymentalnej, przeprowadzał z innymi fizykami doświadczenia. Był członkiem Towarzystwa Królewskiego w Londynie, pierwszym profesorem fizyki eksperymentalnej na Uniwersytecie w Paryżu oraz członkiem Francuskiej Akademii Nauk (od 1739 r.). Po powrocie do Francji od 1735 r. prowadził pokazy fizyki doświadczalnej, dostępne dla wszystkich - bez względu na płeć i warstwę społeczną ${ }^{32}$. W latach czterdziestych XVIII w. był czołową postacią tej dziedziny wiedzy nie tylko w Europie ${ }^{33}$. Dla Nolleta fizyka eksperymentalna to głównie pokazy doświadczalne, które każdy mógłby zrozumieć. Te prowadzone przez niego zawierały więc mało algebry, geometrii czy pytań metafizycznych. Nollet doskonale wiedział, jak przyciągnąć i zatrzymać uwagę audytorium ${ }^{34}$. Chciał popularyzować ${ }^{35}$ naukę, dlatego wykładał po francusku, a nie po łacinie. Dużą uwagę przywiązywał do narzędzi wykorzystywanych w doświadczeniach ${ }^{36}$. Zagadnienia fizyki eksperymentalnej przez niego

29 Ibid., s. 164.

30 lbid., s. 180.

31 Szerzej o biografii J.-A. Nolleta zob. J. Torlais, L'Abbé Nollet. Un physician au siècle des Lumières (1700-1770), Paris 1955; D.J. Sturdy, Science and Social Status. The members of the Académie des Sciences, 1666-1750, Woodbridge 1995, s. 389-391; M.R. Lynn, Popular Science and Public Opinion in Eighteenth-Century France, Manchester 2006, s. 21-25.

32 G.V. Sutton, Science for a Polite Society: Gender, Culture, and the Demonstration of Enlightenment, Boulder, Co 1995, s. 141, cyt. za: S. Shapin, The Image of the Man of Science, [w:] The Cambridge History of Science. Vol. 4, Eighteenth-Century Science, red. R. Porter, Cambridge 2008, s. 170; M. R. Lynn, op. cit., s. 24.

33 Na uwagę zasługuje debata z Benjaminem Franklinem na temat elektryczności, zob. szerzej: J. Torlais, Une grande controverse scientifique au XVIIle siècle, „Revue d'histoire des sciences et de leurs applications” t. 9, 1956, nr 4, s. 339-349; por. P. Brenni, Jean Antoine Nollet and Physics Instruments, tłum. L. Pyenson, [w:] The Art of Teaching Physics. The Eighteenth-Century Demonstration Apparatus of Jean Antoine Nollet, red. L. Pyenson, J.-F. Gauvin, Sillery (Québec) 2002, s. 12-13.

34 P. Brenni, op. cit., s. 13.

35 Opat Nollet był wzorem dla innych popularyzatorów nauki, którzy dzięki tego rodzaju pokazom zaczęli w ten sposób zarobkować i kontynuować pasje badawcze. Zob. M.R. Lynn, op. cit., s. 21; D. Roche, Natural History in the Academics, [w:] Cultures of Natural History, red. N. Jardine, J.A. Secord, E.C. Spary, Cambridge 1996, s. 137.

36 O roli narzędzi wykorzystywanych przez J.-A. Nolleta i ich tworzeniu zob. szerzej P. Brenni, op. cit. s. 11-27; A. Turner, Sciences, Arts, and Improvement: Jean Antoine Nollet, from Craftsman to Savant, [w:] The Art of Teaching Physics, s. 29-46. Cibelle Celestino Silva mówi nawet o 350 narzędziach wykorzystywanych przez Nolleta, zob. C.C. Silva, Jean Antoine Nollet's Contribution to the Institutionalization of Physics, [w:] Brazilian Studies in Philosophy and History of Science. An Account of Recent Works, red. D. Krause, A. Videira, Dordrecht 2011, s. 133. 
prezentowane obejmowały szeroko pojęte działy dzisiejszych: fizyki, chemii, astronomii, biologii oraz innych nauk matematyczno-przyrodniczych.

Na pokazy fizyczne Nolleta w Paryżu uczęszczał Józef Jerzy Hylzen. Już pierwsze zajęcia przyniosły bardzo precyzyjny opis doświadczeń:

Tego dnia barzo ciekawe czynił eksperiencje [o] ogniu. Najpierwej mówił, że nie masz żadnego materiału, który by w sobie ogniste nie zawierał partykułki, które wynikają, przez wielką jaką zebrawszy się komocję. Te zaś partykułki ognia są wielorakie, kiedy bowiem stal o krzemień biją, niektóre są białawo-ogniste, drugie czerwonawe, na powietrzu gaszące się, trzecie prosto na papier lub co inszego spadające. Te partykułki ognia zgaszone przez microscopium widziane różne mają figury, kt.re wielce do galasowych gałek są podobne. Potem czynił eksperie[n]cję z fosforu, którego malutki kawałe[k] między papierem włożywszy i nieco końcem noża barzo mało potar[ł]szy, wraz wybuchł z wielką wiolencją. Fosfor, który do 1730 w wielkim sekrecie zostawał w Angly, w całym teraz wiadomy Paryżu, który z uryny barzo sztucznie czyni się ${ }^{37}$.

Hylzena bardzo zainteresowały doświadczenia, bo niczemu innemu w swoim dzienniku nie poświęcił tyle miejsca. Zaledwie dwa dni później Hylzen wysłuchał wykładu Nolleta o ogniu i stosowaniu go w celu zmiany właściwości metalu ${ }^{38}$. Kolejne pokazy nie wywołały najwidoczniej takiego poruszenia w młodzieńcu, skoro tylko wspomniał, że się odbyły (31 lipca, 4 sierpnia 1753 r.) lub zapisał temat lekcji („,bieg gwiazd i planet”, elektryzacja).

Krótko po tych zajęciach u Nolleta, 9 sierpnia 1753 r., Hylzen zwiedził gabinet naturalny mieszczący się w ogrodach królewskich, w którym - jak przytoczył - „różnych zwierząt s[z]k[i]elety znajdują się, jako to wołów, byków, osłów, baranów, skorpiony, różne motyle, węże, gadziny, ciele morskie. Sistema copernicanum barzo piękne, całe pozłocone, na którego wierszu ozdoby znajduje się"39. Widoczne jest wprowadzenie pewnej systematyki wiedzy do tego gabinetu - nie ma już w nim osobliwości, kuriozów, eksponaty obejmują konkretną tematykę.

Przerwa w pokazach opata Nolleta spowodowała jeszcze większe zainteresowanie naukami fizycznymi młodzieńca. Można wysnuć taki wniosek po coraz dłuższych i coraz dokładniejszych opisach doświadczeń. Nie były one wcale taką prostą sprawą, zważywszy na to, że w Hylzen pisał dziennik po polsku, wykłady zaś odbywały się w języku francuskim. Publikacje Nolleta były znane w Rzeczypospolitej, a podstawy fizyki doświadczalnej młody Hylzen zdobył jeszcze w Wielkim Księstwie Litewskim ${ }^{40}$. W czasach saskich nauki przyrodnicze prężnie się rozwijały w ośrodkach takich jak Wilno, Warszawa czy Poznań,

37 Juozapo Jurgio Hilzeno 1752-1754, s. 180-181.

38 Ibid., s. 181.

39 Ibid., s. 185

40 Por. informację o uczestnictwie młodego magnata w popisie akademickim: „O godzinie drugiej po południu w Kościele XX. Jezuitów św. Jana odprawił się akt solenny Akademicki Promotionis ad supremam AA. LL. Philosophie Lauream Jchmćiow Akademików praevid disputatione publica ex universa Philosophia z dedykacją całego Aktu Jmśi P. Józefowi Hylzenowi [podkreślenie - J.O.] kasztelanicowi Inflantskiemu synowi Jmci P. Marszałka Trybunału Głównego Wielkiego X. L. Który sam z całym Trybunałem był przytomny temu aktowi [...]”, „Kuryer Polski", 9 VIII 1749, s. DCLXXIV. 
a w wileńskim Collegium Nobilium odbywały się otwarte pokazy fizyczne ${ }^{41}$. W stosowaniu prawidłowej terminologii naukowej mógł pomagać młodzieńcowi jego guwerner - Karol Wyrwicz. Dzięki temu otrzymaliśmy dokładne i zrozumiałe opisy eksperymentów w języku polskim, a wiele z nich zostało podobnie zapisanych $w$ fachowych publikacjach z zakresu fizyki doświadczalnej z lat sześćdziesiątych XVIII w. autorstwa Samuela Chróścikowskiego (1730-1799)42 i Józefa Rogalińskiego (1728-1802) ${ }^{43}$.

Wracając jednak do pokazów eksperymentalnych Nolleta, od listopada 1753 r. do 8 maja 1754 r. Hylzen wziął udział w prawie 20 zajęciach i coraz skrupulatniej je opisywał. Tematyka zajęć była niezwykle zróżnicowana. Dotyczyły one „podzielności ciał"44, ich porowatości ${ }^{45}$ czy ruchu (eksperymenty związane z kołyską Newtona) ${ }^{46}$, siły odśrodkowej i dośrodkowej ${ }^{47}$, ciężkości rzeczy ${ }^{48}$ i trzech stanów skupienia materiii ${ }^{49}$. Niejednokrotnie

41 J. Orzeł, A. Pacevičius, S. Roszak, Diariusz Józefa Jerzego Hylzena na tle pamiętników XVIII stulecia, [w:] Juozapo Jurgio Hilzeno 1752-1754, s. 40.

42 S. Chróścikowski, Fizyka doświadczeniami potwierdzona albo doświadczenia fizyczne przez kawalerów filozofii uczących się w Collegium Nobilium Sch: Piarum publicznie czynione, Warszawa 1764.

43 J. Rogaliński, Doświadczenia skutków rzeczy pod zmysły podpadających w publicznych posiedzeniach w szkołach poznańskich Societatis Jesu na widok wystawione i wykładane..., Poznań 1765. O Rogalińskim zob. szerzej F. Chłapowski, Józef Rogaliński - uczony poznański czasów Oświecenia, fizyk, astronom, pedagog, Poznań 2007; Z. Śmierzchalski, Fizyka doświadczalna jako dziedzina filozofii w okresie oświecenia w Polsce na przykładzie dzieł Józefa Rogalińskiego SJ (1728-1802), Kraków 1998.

44 „Mówił najpierwej de divisibilitate corporum oraz eksperiencjami pokazywał, że na koniec noża proszku karminu włożywszy, można zafarbować 20 garców wody. Granum złota na sto mil łatwo extendere może. Kawałki miedzi do jednego kieliszka włożone, a żelaza do drugiego, do nich aquam fortem wlawszy, różny czynią skutek. W jednym aqua fortis, która z siebie jest biała, w niebieski się obróciła się kolor i całą miedź skruszyła. W drugim mocno wreła i także żelazo skruszyła. Potem wziąwszy une piece de deux sous pody spód i na wierz[ch] siarkę podłożył i onę zapalił. Z jednej strony cała się spaliła, z drugiej zaś była cała i tak cienka, że ją łacno złamać można". Juozapo Jurgio Hilzeno 1752-1754, s. 215-216.

45 Nollet „prezentował cylinder szklany, na którego wierzchu była puszka dno dębowe mająca i do tej puszki merkuriuszu wlał i per machinam pneumaticam wywindowawszy z cylindra powietrze, merkuriusz przeszedł na dół przez pory dębu na kształ[t] sreb[r]nego deszczu. Potem pokazał, że merkuriusz przez skórę bawoła przechodzi, kiedy jest przyciśniony. Jajka świeże są pełne, dlatego barzo mało albo nic porów nie mają. Stare zaś dlatego się umniejszają, aby płodowi miejsce dały. Jajka zaś, aby zawsze świeże były, trzeba rozpuścić lak in spiritu vini i do niego jajka wpuścić. Pokazał potem, że napisawszy avec la litarge d'or, które żadnego koloru nie ma, położywszy to w księdze i przycisnąwszy, namazawszy trochę orpiną, charakter widzieć można, acz orpina od litarge d'or o 40 kart circiter może być oddalona". Ibid., s. 216-217.

46 „Pokazał, że corpus mające $4^{\circ}$ prędkości, gdy na drugie natrafi równej z[e] sobą masy, daje mu $2^{\circ}$ prędkości, a dwa sobie zatrzymuje. Co się tyczy corpora niemające elasticitatem, te $2^{\circ}$ daje prędkości, a 2 rezystencji2. Na przykład kula z[e] słoniowej kości, kiedy uderza drugą kulę, ta, która uderzona była, tyle ma prędkości, ile ma kula uderzająca własnym, a nie natężonym jakim innym impetem. Tym się to dzieje, że zawiesiwszy kilkanaście kul w równej linii, gdy pierwsza ręką ludzką na $12^{\circ}$ na przykład od innych odwiedziona, a potem spuszczona w nie uderza i prędkość swoją komunikuje. Pierwsza po sobie kula, ta drugiej, druga trzeciej, aż do ostatniej, która sama jedna tylko od drugich na $12^{\circ}$ odbiega. Po tych eksperiencjach eksplikował motum compositum, to jest, że gdy 2 różne przyczyny w różnych zostające pozycjach, na przykład jednej horyzontalnej, drugiej perpendykularnej, rzecz jaką poruszają, która poruszona medium motum między tymi dwoma pozycjami medium bierze. Dlatego gdy w biegu na koniu siedzący kawaler pomarańczę w górę prosto rzuca, pomarańcza nie za nim, lecz na głowę jego lub przed nim pada". Ibid., s. 218-221.

47 Pokazał, że „jedna od centrum swojego odbiega, a druga do niego dąży. Jeżeli jednak z nich która dalsza jest od centrum, przez co ma więcej prędkości, tedy drugą bliższą do centrum zarywa i z[e] sobą do końca linii mediant motu pędzi. Kiedy zaś są w równej od centrum odległości obie dwie in centro zatrzymują się". Ibid., s. 221.

48 Nollet mówił o "ciężkościach rzeczy i dowiódł, że wszystkie rzeczy w pierwszym momencie swego upadku równo upadają przez jedną sekundę, piętnaście sążni wymierzając, przez drugą zaś - 45", przez 3cią - 15 etc., zawsze nierówną obserwując liczbę. Toż samo się praktykuje, gdy kamień per superficiem nachylonej Ziemi bieży, acz nie z taką prędkością dla ocierania się. Stąd pochodzi, że rzecz upadająca z równym nie bieży impetem, z którym upadać zaczyna, chyba przez schody upadając". Ibid., s. 223.

49 Zajęcia o wodzie i jej trzech stanach: „jako to w stanie likworu, waporu i lodu. Mówił, że woda na przykład Sekwany jest lepsza i zdrowsza nad wodę, która przez kamienie przechodzi lub przez skały. Pokazywał też, że woda, która się przezroczysta i klarowna pokazuje się, nie jest zawsze czysta, że chcąc wodę wyczyścić nieco 
Nollet odnosił się do wiedzy i doświadczeń innych badaczy, jak chociażby wówczas, gdy „traktował o ciężkości rzeczy, którą dotychczas filozofowie dostatecznie wyeksplikować nie mogą. Newton zakłada ją na atrakcji generalnej jednej rzeczy do drugiej. Kartezjusz, że materia pewna obraca ją około świata i rzeczy do centrum Ziemi kieruje" ${ }^{50}$. Można również podzielić zajęcia Nolleta zgodnie z dzisiejszymi działami nauki: hydrostatyką ${ }^{51}$, aerostatyką (gdy fizyk pokazywał, że ogień nie istnieje bez powietrza ${ }^{52}$ ) lub fizjologią organizmów żywych - demonstrując, że muszą one oddychać tlenem ${ }^{53}$. Zajął się także m.in. fosforami czy tęczą:

Pokazywał, że każdy kamień uderzony o drugi, jeżeli ma iskry, to światło wynika. Prezentował potem 2 rodzaje fosforów. Jedne, które w ciemnie się świeci, i pisząc, ogniste ryje litery, które około pół godziny trwają. Drugie, gdy jest z flaszki wyjęte, w ogień się obraca. Mówił także o kolorach, który twierdzi, że z promieniów słonecznych pochodzą i że w samej rzeczy nie są. Pierwszy kolor jest czerwony, 2 - pomarańczowy, 3 - cytrynowy, 4 - zielony, 5 - niebieski, 6 - purpurowy etc. ${ }^{54}$

Jeśli chodzi o astronomię, Nollet odrzucał system geocentryczny (ptolemejski, jak zaznaczył Hylzen) i przyjmował kopernikański ${ }^{55}$. To oczywiście tylko przykłady eksperymentów. Ostatnie zajęcia u opata nie były już tak drobiazgowo opisywane. Młodzieniec zaledwie wspominał, że się odbyły, czasem tylko podając tematykę: „de porositate corporum"56,

(bo wcale ją wyczyścić nie można, ponieważ subtelniejsze w sobie różnych korpusów zawierają partykułki), można albo przecedzić, albo destylować, i że piasek wcale wodę nie czyści, co sam JMX Nollet doświadczył, prze[z] piasek długo barzo wodę przepuszczając". Ibid., s. 230-231.

50 Ibid., s. 222.

51 Nollet „powiedział, że te rzeczy, które są in aequilibrio, gdy do wody są wnurzone aequilibrium tracą. Potem czynił eksperiencje. Naprzód nad wodą zafarbowaną, do której kilka trzy tuby włożywszy, od 6 albo 7 linii z obydwóch końców otwarte, z wierzchu jednak palcem zawarte, gdy otwierają się, palec odejmując, woda na 6 albo 7 linii diametru wynika. Szklane tubum do wody wnurzywszy i z niego powietrze wyciągnąwszy, woda dochodzi i tubum napełnia. Taż sama z merkuriuszem staje się eksperiencja z tą jednak dyferencją, że tubus 30 calów mieć natenczas powinien i merkuriusz nad 271/2 calów 1/2 nie podnasza się. Cylinder szklany wodą napełniony nie ciecze, kiedy do niego papier jest przyłożony, tak aby dobrze brzegów się dotykały, partykularnie do horyzonta przewrócony. Tubus krzywy, kiedy [do] naczynia jakim likworem napełnionego wkłada się i powietrze gębą lub małą pompą wyciąga się, likwor aż do końca wycieka”. Ibid., s. 223; „Byliśmy na lekcji fizycznej JMX Nolletta, który traktował o stanie solidów do jakiego likworu wmoczonych. Pierwsza eksperiencja była [taka], że woda zafarbowana w pęchyrzy i do tubu szklanego przywiązana, gdy w wodzie tonie, tyle pod[e]jmuje się, ile jest zanurzona, nigdy jednak wody superficiem nie przechodzi. Corpus jakie, które z drugim na powietrzu jest in aequilibrio, gdy się znajduje w wodzie, wcale aequilibrium traci i chcąc, aby miało toż aequilibrium w wodzie, drugą tak wiele moc mu dać potrzeba. Na przykład kiedy corpus ma 3 cale na powietrzu, drugie mu 3 dać potrzeba, chcąc, aby było z drugim in aequilibris". Ibid., s. 225.

52 Ibid., s. 229.

53 Nollet „pokazywał, że żadne zwierzę bez powietrza żyć nie może. Ptaszek w machinę pneumatyczną włożony, gdy z niej powietrze wychodzi, w konwulsje wpada i gdy w tym przez jaki[ś] czas znajduje się stanie, zdycha. Gdy jednak prędko powietrze przywracają, ożywia się w krótkim czasie, lecz ordynaryjnie nie na barzo długo. Rybę do szklanicy wodą niemal napełnioną włożywszy i per machinam pneumaticam powietrze wywindowawszy, ryba zawsze na wierzchu pływa, nie mogąc iść na den. I gdy eksperiencja trwa kilka godzin, ryba zdycha, a gdy powietrze znowu wchodzi, ryba czy żywa, czy zdechła, nigdy już więcej na wierzch nie wychodzi". Ibid., s. 227.

54 Ibid., s. 233.

55 Ibid., s. 239.

56 Ibid., s. 241 
„o prędkości corporum”57, o hydrostatyce ${ }^{58}$, „o ciężarze likworów”59 , „o tubach kapilarnych"60, o mechanice ${ }^{61}$, o pomiarze gęstości cieczy ${ }^{62}$.

Wspomniano już, że Nollet dużą wagę przywiązywał do narzędzi wykorzystywanych w swoich eksperymentach. Na zajęciach prezentował chociażby urządzenia związane z wodą, jak dzwon nurkowy służący do transportu nurków na różne głębokości ${ }^{63}$ czy fontannę wyrzucającą wodę w nierównych odstępach czasu.

W XVIII W. większość społeczeństwa wciąż nie miała dostępu do gabinetów prywatnych. Jedynymi miejscami, w których można było zobaczyć kurioza, były skarbce kościołów. Aby dostać się do gabinetów kolekcjonerów, trzeba było należeć do tego samego środowiska lub/i mieć odpowiednie koneksje ${ }^{64}$. Nollet rozbudził u Hylzena ciekawość świata, a paryskie eksperymenty stały się idealnym pomostem do gabinetów innych wielkich uczonych drugiej połowy XVIII w. To właśnie fizyk poprosił René Antoine'a Ferchault de Réaumura (1683-1757), aby młody szlachcic z Rzeczypospolitej wraz ze swoim jezuickim opiekunem mogli zobaczyć jego gabinet rzadkich okazów, cabinet de raretés, jak sam stwierdził Hylzen. Réaumur już jako 28-latek został członkiem Królewskiej Akademii Na$u^{65}$ - przede wszystkim dzięki osiągnięciom w dziedzinie geometrii. Jego jednak bardziej fascynowała historia naturalna, zoologia, botanika, a także produkcja porcelany, hutnictwo, metalurgia. Réaumur jest znany przede wszystkim właśnie z owego przywołanego przez Hylzena gabinetu osobliwości. Znajdowały się w nim także eksponaty z obszaru Rzeczypospolitej Obojga Narodów. Informacje i okazy z jej terenów Réaumur uzyskiwał przede wszystkich od Franciszka Bielińskiego (ok. 1683-1766), z którym najpewniej kontaktował się w czasie jego pobytu w Paryżu w 1747 r. ${ }^{66}$

Cztery dni po rozmowie opata Nolleta z Hylzenem i Wyrwiczem, 18 sierpnia 1753 r., goście znad Wisły byli już u współpracownika fizyka. Réaumur bardzo serdecznie ich przywitał i „godne widzenia rzeczy pokazał”. W przeciwieństwie do gabinetu w Wiedniu tym razem Hylzen opisał dokładnie, cóż paryski przyrodnik im demonstrował:

Prezentował najpi[e]rwej nam, jak kurczęta z jajek wychodzą w cieple schowane. Jest bowiem tam skrzynia, we śrzodku której są położone jajca. Z tyłu skrzynia nakryta jest gnojem końskim, które dodaje ciepła do wychodzenia kurczętom

57 lbid., s. 244.

58 lbid., s. 244.

59 Ibid., s. 246.

60 Ibid., s. 246.

61 Ibid., s. 246.

62 lbid., s. 247.

63 „Prezentował nam figurę la cloche de plongeurs, która wymyślona była, aby człowiek więcej niż 15 minut mógł być pod wodą (bo najlepszy nurek dłużej wytrzymać nie może). Machina ta do wielkich głębokości zażywana być nie mogła dla znacznego wody ciężaru [...]". Ibid., s. 216.

64 K. Pomian, op. cit., s. 58.

65 P. Daszkiewicz, René Antoine Ferchault de Réaumur (1683-1757), a Naturalist and Pioneer of Acarology and his Contacts with Poland, „Biological Lett." 2016, nr 53 (1), s. 9.

66 Idem, Polonika w archiwum René-Antoine Ferchault de Réaumur (1683-1757), „Kwartalnik Historii Nauki i Techniki" t. 54, 2009, nr 2, s. 85-86. Szerzej na temat relacji między nimi w tekście P. Daszkiewicza, w którym przytoczone zostały też ich listy: idem, Cabinets de curiosités, oiseaux du Nord, minéraux et expériences physiques ou la correspondance scientifique entre René-Antoine Ferchault de Réaumur (1683-1757) et quelques curieux de la Pologne du XVIII e siècle, „Annales de Centre Scientifique de I'Academié Polonaise des Sciences à Paris" 2008, nr 11, s. 278-292. 
z jajek. Aby zaś ciepło niezbyt wielkie ani małe było, są położone na jajcach termometra, które według JMP Reomura roboty od 32 gradum ciepła. Pokazał nam potem miejsce, gdzie się hodują. I takim sposobem, kiedy żadnego w Paryżu nie masz kurczęcia, u niego w obfitości znajdują się. Pokazywano nam potem le cabinet de rar[e]t[e]s, w którym różne zwierzęta, miner[ał]y, mumie, s[z]k[i]elety etc. znajdują się, różne motyle przedziwne ze wszystkich czterech świata części zebranych $^{67}$.

Pierwsza część opisu dotycząca wylęgu i hodowli kurcząt to doświadczenia, których wyniki Réaumur zawarł w swej książki z 1749 r. na temat Art de faire éclore et d'élever en toutes saisons des oiseaux domestiques de toutes espèces (Sztuki wylęgu i hodowli ptactwa domowego wszelkiego rodzaju we wszystkich porach roku). Réaumur stworzył „pierwsze w Europie inkubatory do wylęgu kurzych jaj"68. Hylzen wspomniał też o termometrze skonstruowanym przez tego uczonego. Réaumur rzeczywiście był znanym konstruktorem termometru i twórcą skali temperatury, zwanej od jego nazwiska "skalą Réaumura"69. Druga część relacji Hylzena to opis poszczególnych kolekcji gabinetu. Réaumur starał się nie tylko mieć każdy interesujący go gatunek, lecz przede wszystkim analizować cechy i zachowanie posiadanych zwierząt, ptaków, insektów. Dla niego gabinet był miejscem pracy. To już nie gabinet osobliwości (mimo że Hylzen wciąż go tak nazywa), to gabinet naturalny, a raczej, zgadzając się z Piotrem Daszkiewiczem - muzeum historii naturalnej70. Wreszcie to narzędzie pracy oświeconego badacza. Mamy tu do czynienia ze zderzeniem dwóch perspektyw oceny gabinetu i jego kolekcji. Z jednej strony to obserwacja podróżnika, dla którego zbiór jest tradycyjnym gabinetem osobliwości. Osobliwości te należy zobaczyć, opisać, by po powrocie z podróży móc się pochwalić samą wizytą. Z drugiej strony to nowa perspektywa oceny tego miejsca jako gabinetu pracy uczonego, gdzie nie tylko prezentuje się eksponaty, lecz także - a może nawet przede wszystkim poddaje się je badaniom.

Kolekcja Réaumura była jedną z największych w Europie, choć nie mógł się on w tej kwestii równać z Hansem Sloanem (1660-1753). Ten swoją kolekcję przekazał narodowi brytyjskiemu i w ten sposób stała się ona podstawą zbiorów British Museum, otwartego publicznie w 1759 r. ${ }^{71}$ Po śmierci Réaumura jego bratanek Mathurin Jacques Brisson (1723-1806) połączył jego gabinet z gabinetem królewskim, mimo że sam Réaumur zamierzał go przekazać Akademii. Na marginesie warto dodać, że Brisson był jednym z najważniejszych nauczycieli Stanisława Staszica72.

Pytanie, jakie nasuwa się po takim opisie gabinetu naturalnego, brzmi: co skłoniło Hylzena do dokładniejszego niż dotychczasowe przytoczenia zawartości gabinetu? Wyda-

67 Juozapo Jurgio Hilzeno 1752-1754, s. 191.

68 P. Daszkiewicz, René Antoine Ferchault de Réaumur (1683-1757) - dendrologiczne aspekty jego prac, „Rocznik Polskiego Towarzystwa Dendrologicznego" t. 64, 2016, s. 60.

69 Ibid.

70 Idem, Polonika, s. 83.

71 Sir Hans Sloane (1660-1753) Founder of the British Museum, „JAMA: The Journal of the American Medical Association" 1969, nr 207 (5), s. 943. O jego kolekcji zob. m.in. J. Delbourgo, Collecting the World. The Life and Curiosity of Hans Sloane, London 2017; From Books to Bezoars: Sir Hans Sloane and His Collections, red. M. Hunter, A. MacGregor, A. Walker, London 2012; Enlightenment: Discovering the World in the Eighteenth Century, red. K. Sloan, London 2003; Sir Hans Sloane: Collector, Scientist, Antiquary, London 1994.

72 P. Daszkiewicz, Polonika, s. 84. 
je się, że to dzięki osobistej relacji z Nolletem, fascynacji jego wykładami młody magnat z Rzeczypospolitej tak precyzyjnie opisał gabinet Réaumura. Precyzja zapisu wynikała też zapewne z doświadczenia, jakiego nabrał Hylzen w relacjonowaniu samych eksperymentów Nolleta. Widać wyraźnie, że jako uczeń młodzieniec doskonali swój styl, a co ważniejsze - posługuje się terminologią z kolejnych dyscyplin wiedzy. Wyjaśnijmy w tym miejscu, skąd Nollet znał Réaumura. Na początku lat trzydziestych XVIII w. Nollet został asystentem w laboratorium Réaumura ${ }^{73}$. Potrzebny był mu człowiek, który miał doświadczenie w przeprowadzaniu eksperymentów oraz konstruowaniu nowych instrumentów, machin, narzędzi do przeprowadzania kolejnych doświadczeń.

Nollet znał jednak nie tylko Réaumura. W 1735 r. Nollet wyjechał do Holandii, gdzie spotkał się z Pieterem van Musschenbroekiem (1692-1761), Willemem Jacob'sem Gravesandem (1688-1742) i Jean-Nicolas-Sébastienem Allamandem (1716/1713-1787) ${ }^{74}$. Relacje z nimi, utrzymywany przez lata dzięki korespondencji kontakt miały ogromny wpływ na nauki eksperymentalne we Francji. Dlaczego informacja o kręgu uczonych z Niderlandów związanych z paryskim fizykiem jest dla nas istotna? Po niemalże rocznym pobycie w Paryżu Hylzen wracał do Rzeczypospolitej przez Niderlandy.

W Lejdzie peregrynant zwiedził najpierw bibliotekę (zapewne uniwersytecką), w której podziwiał system kopernikański. Następnie był „w gabinecie naturalnym, w którym różne rzeczy ciekawe znajdują się, jako wszystkie członki ludzkie, monstra różne, krokodyle, leopardy, niedźwiedzie białe etc., mumie egipskie od tysiąca lat cudzoziemskie barzo wielkie" $^{\prime 75}$. Zapewne Hylzen miał na myśli miejsce, które wiek wcześniej Giacomo Fantuzzi nazwał Anatomią - i jego też przyciągały tu osobliwości, „wypchane w całości ciała zwierząt przeróżnych, wszystkich gatunków, jakie na świecie spotkać można”, "rozmaite stojące szkielety mężczyzn i kobiet w całości i z kośćmi razem połączonymi"76.

W Lejdzie podróżnik z Rzeczypospolitej odwiedził także Pietera van Musschenbroeka. Matematyk, filozof, astronom, przede wszystkim jednak twórca butelki lejdejskiej, czyli pierwszego kondensatora, urządzenia służącego do gromadzenia ładunku elektrycznego, był współpracownikiem i przyjacielem znanego nam już Réaumura i to z tego powodu najpierw, w latach trzydziestych pojawił się u niego Nollet. W styczniu 1746 r. van Musschenbroek napisał o odkryciu butelki lejdejskiej Réaumurowi, ale pojęcie „butelka lejdejska" to nazwa wprowadzona do obiegu naukowego przez Nolleta77 - który tłumaczył z łaciny list Musschenbroeka do Réaumura.

W latach pięćdziesiątych Hylzen zatem znów zapewne dzięki Nolettowi w czasie swej podróży edukacyjnej odwiedził kolejnego uczonego przyrodnika. Jak wygląda opis gabi-

73 Część badaczy mówi o 1733, część o 1732 r. M.R. Lynn, op. cit., s. 22; M.J. Dubois, La science expérimentale et les cabinets de physique au XVIIle siècle, „Bulletin de la Societé Archéologique de Touraine” t. 42, 1989, bez paginacji; C.C. Silva, op. cit., s. 134

74 M.J. Dubois, op. cit., bez paginacji. O ich współpracy zob. m.in. T. Cocquyt, Failure, Fraud and Instruments Cabinets: Academic Involvement in the Eighteenth-Century Dutch Water Crisis, [w:] Cabinets of Experimental Philosophy in Eighteenth-Century Europe, red. J. Bennett, S. Talas, Leiden, Boston 2013, s. 79-98.

75 Juozapo Jurgio Hilzeno 1752-1754, s. 267.

76 G. Fantuzzi, Diariusz podróży po Europie (1652), tłum. i oprac. W. Tygielski, Warszawa 1990, s. 114. Szerzej zob. H. Hooijmaijers, A. Maas, Entrepreneurs in Experiments: The Leiden Cabinet of Physics and the Motives of its Founders (1675-1742), [w:] Cabinets of Experimental Philosophy, s. 27-48.

77 W. Maver jr., Electricity, its History and Progress, [w:] The Encyclopedia Americana: a library of universal knowledge, t. 10, New York 1918, s. 179. 
netu profesora uniwersytetu w Lejdzie pióra Józefa Jerzego? „Gabinet JMP Machembroka barzo piękny, w którym mechaniczne, optyczne, elektryczne ordynaryjne machiny znajdują się, speculum aussivum (zwierciadło powiększające), którym wszystkie metale można stopnąć etc."78. Od razu po tym nastąpiła wizyta u współpracownika van Musschenbroeka - Jean-Nicolas-Sebastiena Allamanda. Twórca gabinetu historii naturalnej Uniwersytetu w Lejdzie także posiadał własny gabinet osobliwości, otwarty dla studentów i znajdujący się w budynku akademii. Notabene po śmierci - zgodnie z wolą Allamanda - został on przekazany uniwersytetowi. Hylzen opisał go tymi słowami: gabinet

także jest dobry, do niego należy gabinet anatomiczny i ogród naturalny. W ogrodzie rosną różne produkcje nieznajome, jako to planty, z których wychodzi cukier, ananas, kawy frukta etc. W gabinecie anatomicznym są zwierzęta cudzoziemskie, konchy barzo piękne, cejlońskie i inne minerały, złota, srebra etc., marmury różnych krajów, agaty etc. ${ }^{79}$

To ostatni z gabinetów, który w swej podróży edukacyjnej Hylzen zwiedził. Analizując jego dziennik podróży, zauważalne są spore różnice w postrzeganiu przez niego rzeczywistości. Początkowe relacje młodzieńca są bardzo mocno osadzone w barokowej kulturze ciekawości. Detaliczny opis kościołów czy pałaców i ich skarbców ${ }^{80}$ oraz gabinetów osobliwości, w których znajdowały się najróżniejsze rzeczy, służył przede wszystkim odnotowaniu „rzeczy godnych widzenia". Świat barokowy opierał się na chęci zobaczenia i odnotowania tego, co niezwykłe. Hylzen jednak, zainteresowany naukami przyrodniczymi, spotkał na swojej drodze opata Nolleta. Zafascynowany uczonym, ale i popularyzatorem fizyki eksperymentalnej przejmuje od niego nową wizję świata - on także chce zrozumieć te eksperymenty, objaśnić je sobie, może i innym po powrocie do kraju. Nie wystarczy już zobaczenie, rodzi się w nim inny rodzaj ciekawości, chęć zrozumienia, oświecenia własnego umysłu. Stąd tak precyzyjne opisy doświadczeń wykonywanych przez opata.

Widoczne jest, jak bardzo relacja z jednym uczonym - Jean-Antoinem Nolletem determinowała stosunki z innymi uczonymi. Dzięki tej znajomości Hylzen wkroczył do świata osiemnastowiecznych przyrodników, fizyków. Zapewne to francuski opat był informatorem udzielającym rad, do kogo należy pojechać, zapewne rekomendował gości z Rzeczypospolitej lub napisał stosowne poręczenia. Dzięki kontaktom z wybitnymi przedstawicielami świata nauk przyrodniczych młodzieniec z Inflant miał okazję zobaczyć z bliska ich gabinety. To właśnie w połowie XVIII w. kategoria osobliwości traciła na znaczeniu, osobliwości zaczęły znikać z kolekcji, bo te zaczęły się specjalizować81. Widoczne jest to na przykładach gabinetów odwiedzanych przez Hylzena. To gabinety naturalne, skategoryzowane, zbiory bardziej uczone, które potem stały się fundamentami kolekcji dzisiejszych muzeów.

78 Juozapo Jurgio Hilzeno 1752-1754, s. 267.

79 Ibid., s. 269. O niderlandzkich gabinetach naturalnych zob. szerzej: H.J. Zuidervaart, Cabinets for Experimental Philosophy in the Netherlands, [w:] Cabinets of Experimental Philosophy, s. 1-26.

80 Największe wrażenie na Hylzenie zrobił skarbiec znajdujący się w kaplicy zamkowej w pałacu cesarskim w bawarskim Altötting, którą niezwykle szczegółowo opisał diarysta. Juozapo Jurgio Hilzeno 1752-1754, s. 140-143. Por. S. Hofmann, Die Heilige Kapelle zu Altötting (aus Kirchenrechnungen und Klosterliteralien), Schongau 1959.

81 M. Mencfel, Osobliwy, czyli jaki?, s. 23-24; J. Czerzniewska, op. cit., s. 34. 
Mimo podnoszonej w XVIII w. krytyki zagranicznych wojaży - zarówno w sferze edukacyjnej, moralnej, jak i finansowej - zdarzało się, że młodzież nie tylko ugruntowywała swą wiedzą, lecz także ją pogłębiała, znajdując interesujące ją wątki, m.in. dzięki kontaktowi z uczonymi, których odwiedzano. Jest to widoczne zwłaszcza wśród oświeconych peregrynantów z drugiej połowy XVIII w., doceniających uroki antykwaryzmu, idealne piękno sztuki klasycznej i kolekcjonerstwo ${ }^{82}$. Skategoryzowane kolekcje, które odwiedzał Hylzen, są już częścią przyszłych muzeów, a „muzeum to instytucjonalizacja ciekawości”83. Młody peregrynant z Inflant jest świadkiem, a nawet uczestnikiem tego procesu, a jego dziennik to ciekawe świadectwo indywidualizacji zainteresowań podróżnika połowy stulecia, jak i poszerzania się jego perspektywy poznawczej. Lata pięćdziesiąte XVIII w. to nie tylko zmiana w sposobie prowadzenia narracji w dziennikach i pamiętnikach, dopuszczanie do głosu sfery emocjonalnej. To także (często nieuświadomiona) zmiany podróży edukacyjnej w podróż „uczoną" (peregrinatio scientifica).

\section{Bibliografia}

\section{Źródła drukowane}

Chróścikowski S., Fizyka doświadczeniami potwierdzona albo doświadczenia fizyczne przez kawalerów filozofii uczących się w Collegium Nobilium Sch: Piarum publicznie czynione, Warszawa 1764.

Gawarecki S., Diariusz drogi. Podróż Jana i Marka Sobieskich po Europie 1646-1648, oprac. M. Kunicki-Goldfinger, Warszawa 2013.

Juozapo Jurgio Hilzeno 1752-1754 metụ kelionés dienoraštis / Dziennik podróży Józefa Jerzego Hylzena z lat 1752-1754, red. A. Pacevičius, oprac. J. Orzeł, A. Pacevičius, S. Roszak, Vilnius 2013.

„Kuryer Polski”, 9 VIII 1749.

Ojcowskie synom przestrogi. Instrukcje rodzicielskie (XVI-XVII w.), wstęp i objaśnienia D. Żołądź-Strzelczyk, M.E. Kowalczyk, Wrocław 2017.

Przestrogi i nauki dla dzieci. Instrukcje rodzicielskie (XVIII w.), oprac. D. Żołądź-Strzelczyk, M.E. Kowalczyk, Wrocław 2017.

Rogaliński J., Doświadczenia skutków rzeczy pod zmysły podpadających w publicznych posiedzeniach w szkołach poznańskich Societatis Jesu na widok wystawione $i$ wykładane..., Poznań 1765.

Sobieski J., Peregrynacja po Europie (1607-1613). Droga do Baden (1638), oprac. J. Długosz, Wrocław 1990.

\section{Literatura przedmiotu}

Bratuń M., Grand Tour. Narodziny - rozwój-zmierzch, [w:] Polski Grand Tour w XVIII i początkach XIX wieku, red. A. Roćko, Warszawa 2014, s. 19-30. 
Bratuń M., Z dziejów europejskiego „Grand Tour” w XVII i XVIII wieku, „Kwartalnik Opolski" t. 49, 2003, z. 1, s. 7-12.

Brenni P., Jean Antoine Nollet and Physics Instruments, tłum. L. Pyenson, [w:] The Art of Teaching Physics. The Eighteenth-Century Demonstration Apparatus of Jean Antoine Nollet, red. L. Pyenson, J.-F. Gauvin, Sillery (Québec) 2002, s. 11-27.

Collection, Laboratory, Theater: Scenes of Knowledge in the $17^{\text {th }}$ Century, red. H. Schramm, L. Schwarte, J. Lazardzig, Berlin, New York 2005.

Chachaj M., Zagraniczna edukacja Radziwiłłów od początku XVI do połowy XVII wieku, Lublin 1995.

Chłapowski F., Józef Rogaliński - uczony poznański czasów Oświecenia, fizyk, astronom, pedagog, Poznań 2007.

Cocquyt T., Failure, Fraud and Instruments Cabinets: Academic Involvement in the Eighteenth-Century Dutch Water Crisis, [w:] Cabinets of Experimental Philosophy in Eighteenth-Century Europe, red. J. Bennett, S. Talas, Leiden, Boston 2013, s. 79-98.

Czerzniewska J., Cabinet, kammera, studiolo. Konstrukcja wiedzy o niezwykłych przedmiotach i sztuce, [w:] Curiosità - zjawiska osobliwe w sztuce, literaturze i obyczaju, red. A.S. Czyż, J. Nowiński, Warszawa 2013, s. 26-49.

Daszkiewicz P., Cabinets de curiosités, oiseaux du Nord, minéraux et expériences physiques ou la correspondance scientifique entre René-Antoine Ferchault de Réaumur (1683-1757) et quelques curieux de la Pologne du XVIII ${ }^{e}$ siècle, „Annales de Centre Scientifique de l'Academié Polonaise des Sciences à Paris" 2008, nr 11, s. 278-292.

Daszkiewicz P., Polonika w archiwum René-Antoine Ferchault de Réaumur (16831757), „Kwartalnik Historii Nauki i Techniki” t. 54, 2009, nr 2, s. 83-93.

Daszkiewicz P., René Antoine Ferchault de Réaumur (1683-1757) - dendrologiczne aspekty jego prac, „Rocznik Polskiego Towarzystwa Dendrologicznego” t. 64, 2016, s. 59-66.

Daszkiewicz P., René Antoine Ferchault de Réaumur (1683-1757), a Naturalist and Pioneer of Acarology and his Contacts with Poland, „Biological Lett." 2016, nr 53 (1), s. 9-17, DOI: 10.1515/biolet-2017-0002.

Delbourgo J., Collecting the World. The Life and Curiosity of Hans Sloane, London 2017.

Dubois J.M., La science expérimentale et les cabinets de physique au XVIIle siècle, „Bulletin de la Societé Archéologique de Touraine” t. 42, 1989.

Dziechcińska H., O staropolskich dziennikach podróży, Warszawa 1991.

Dziechcińska H., „Podróż” w druku i rękopisie, [w:] Staropolska kultura rękopisu, red. H. Dziechcińska, Warszawa 1990, s. 113-122.

Enlightenment: Discovering the World in the Eighteenth Century, red. K. Sloan, London 2003.

Fantuzzi G., Diariusz podróży po Europie (1652), tłum. i oprac. W. Tygielski, Warszawa 1990.

Folga-Januszewska D., Muzeum: fenomeny i problemy, Kraków 2015.

From Books to Bezoars: Sir Hans Sloane and His Collections, red. M. Hunter, A. MacGregor, A. Walker, London 2012.

Hofmann S., Die Heilige Kapelle zu Altötting (aus Kirchenrechnungen und Klosterliteralien), Schongau 1959. 
Hooijmaijers H., Maas A., Entrepreneurs in Experiments: The Leiden Cabinet of Physics and the Motives of its Founders (1675-1742), [w:] Cabinets of Experimental Philosophy in Eighteenth-Century Europe, red. J. Bennett, S. Talas, Leiden, Boston 2013, s. 27-48.

Kucharski A., Grand Tour Tomasza, Michała i Marcina Zamoyskich z przełomu XVII i XVIII wieku, „Klio" t. 33, 2015, nr 2, s. 73-101.

Kucharski A., Theatrum peregrinandi. Poznawcze aspekty staropolskich podróży w epoce późnego baroku, Toruń 2013.

Kucharski A., Roszak S., Wieczorek A., O podróżach edukacyjnych w XVII i XVIII wieku - przypadek Rzewuskich, [w:] Społeczne i kulturowe uwarunkowania edukacji Rzeczypospolitej XVI-XVIII wieku. Materiały z badań, część pierwsza, red. K. Puchowski, oprac. J. Orzeł, Warszawa 2017, s. 75-97.

Kutter U., Reisen - Handbücher - Wissenschaft. Materialien zur Reisekultur im 18. Jahrhundert, Neuried 1996.

Lippold F., Gabinety osobliwości i edukacja w państwach niemieckich w XVII i XVIII wieku na przykładzie kunstkamery Augusta Hermanna Franckego w Halle, [w:] Johann Joachim Winckelmann i Stanisław Kostka Potocki. Mistrzowie i uczniowie. Materiały międzynarodowej konferencji zorganizowanej w Muzeum Pałacu Króla Jana III w Wilanowie, Warszawa 8-9 maja 2014 r. T. 1, Nowe badania i dokumenty / Johann Joachim Winckelmann und Stanisław Kostka Potocki. Meister und Schüler. Akten des internationalen Kongresses im Museum Palast König Johann III. in Wilanów, Warschau 8.-9. Mai 2014. Bd. 1, Neue Forschungen und Dokumente, red. P. Jaskanis, M. Kunze, Mainz, Ruhpolding, Warszawa 2016, s. 13-22.

Lynn M.R., Popular Science and Public Opinion in Eighteenth-Century France, Manchester 2006.

Markiewicz A., Podróże edukacyjne w czasach Jana III Sobieskiego. Peregrinationes Jablonovianae, Warszawa 2011.

Markowski M.P., Anatomia ciekawości, Kraków 1999.

Maver jr. W., Electricity, its History and Progress, [w:] The Encyclopedia Americana: a library of universal knowledge, t. 10, New York 1918, s. 171-181.

Mączak A., Odkrywanie Europy. Podróże w czasach renesansu i baroku, Gdańsk 1998, s. 7.

Mączak A., Turystyka europejska. Wieki XVI-XIX, „Folia Turistica” 2008, nr 19, s. 5-26.

Mencfel M., Osobliwy, czyli jaki? Kategoria niezwykłości w kulturze naukowej, artystycznej i kolekcjonerskiej epoki nowożytnej, [w:] Curiosità - zjawiska osobliwe w sztuce, literaturze i obyczaju, red. A.S. Czyż, J. Nowiński, Warszawa 2013, s. 10-25.

Mencfel M., Skarbce natury i sztuki. Prywatne gabinety osobliwości, kolekcje sztuki i naturaliów na Śląsku w wieku XVII i XVIII, Warszawa 2010.

Orzeł J., Pacevičius A., Roszak S., Diariusz Józefa Jerzego Hylzena na tle pamiętników XVIII stulecia, [w:] Juozapo Jurgio Hilzeno 1752-1754 mety kelionés dienoraštis / Dziennik podróży Józefa Jerzego Hylzena z lat 1752-1754, red. A. Pacevičius, oprac. J. Orzeł, A. Pacevičius, S. Roszak, Vilnius 2013, s. 22-58.

Pomian K., Zbieracze i osobliwości. Paryż-Wenecja XVI-XVIII wiek, tłum. A. Pieńkos, Gdańsk 2012.

Poulot D., Musée et muséologie, Paris 2009.

Riedl-Dorn Ch., Chevalier de Baillou und das Naturalienkabinett, [w:] Lothringens Erbe. Franz Stephan von Lothringen (1708-1765) und sein Wirken in Wirtschaft, Wissenschaft und Kunst der Habsburgermonarchie, red. R. Zedinger, St. Pölten 2000, s. 111-115. 
Roche D., Natural History in the Academics, [w:] Cultures of Natural History, red. N. Jardine, J.A. Secord, E.C. Spary, Cambridge 1996, s. 127-144.

Rok B., Zagraniczne podróże Polaków w pierwszej połowie XVIII w., „Śląski Kwartalnik Historyczny 'Sobótka'" t. 47, 1992, z. 1-2, s. 171-178.

Shapin S., The Image of the Man of Science, [w:] The Cambridge History of Science. Vol. 4, Eighteenth-Century Science, red. R. Porter, Cambridge 2008, s. 159-183, https:// doi.org/10.1017/CHOL9780521572439.008.

Silva C.C., Jean Antoine Nollet's Contribution to the Institutionalization of Physics, [w:] Brazilian Studies in Philosophy and History of Science. An Account of Recent Works, red. D. Krause, A. Videira, Dordrecht 2011, s. 131-140.

Sir Hans Sloane (1660-1753) Founder of the British Museum, "JAMA: The Journal of the American Medical Association" 1969, nr 207 (5), s. 943, doi:10.1001/jama .1969 .03150180073016 .

Sir Hans Sloane: Collector, Scientist, Antiquary, London 1994.

Sturdy D.J., Science and Social Status. The members of the Académie des Sciences, 1666-1750, Woodbridge 1995.

Śmierzchalski Z., Fizyka doświadczalna jako dziedzina filozofii w okresie oświecenia w Polsce na przykładzie dzieł Józefa Rogalińskiego SJ (1728-1802), Kraków 1998.

Targosz K., Jana Sobieskiego nauki i peregrynacje, Wrocław 1985.

The Origins of Museums. The Cabinet of Curiosities in Sixteenth- and SeventeenthCentury Europe, red. O. Impey, A. MacGregor, Oxford 1985

Torlais J., L'Abbé Nollet. Un physician au siècle des Lumières (1700-1770), Paris 1955.

Torlais J., Une grande controverse scientifique au XVIIle siècle, „Revue d'histoire des sciences et de leurs applications" t. 9, 1956, nr 4, s. 339-349.

Turner A., Sciences, Arts, and Improvement: Jean Antoine Nollet, from Craftsman to Savant, [w:] The Art of Teaching Physics. The Eighteenth-Century Demonstration Apparatus of Jean Antoine Nollet, red. L. Pyenson, J.-F. Gauvin, Sillery (Québec) 2002, s. 29-46.

Wurzbach C. von, Baillou, Johann chevalier, [w:] Biographisches Lexikon des Kaiserthums Oesterreich, cz. 14, Wien 1865, s. 388-391.

Zuidervaart H.J., Cabinets for Experimental Philosophy in the Netherlands, [w:] Cabinets of Experimental Philosophy in Eighteenth-Century Europe, red. J. Bennett, S. Talas, Leiden, Boston 2013, s. 1-26.

Żołądź-Strzelczyk D., Edukacja Lubomirskich w drugiej połowie XVI i XVII wieku, [w:] D. Żołądź-Strzelczyk, "Pod każdym względem szlachetne ci daję wychowanie...". Studia z dziejów wychowania szlachty w epoce staropolskiej, Wrocław 2017, s. 21-49.

Żołądź-Strzelczyk D., Peregrinatio academica. Studia młodzieży polskiej z Korony i Litwy na akademiach i uniwersytetach niemieckich w XVI i pierwszej połowie XVII wieku, Poznań 1996.

Dr JOANNA ORZEŁ, absolwentka historii (2008) i filologii polskiej (2009), doktor nauk humanistycznych w zakresie historii (dyplom uzyskany na Uniwersytecie Mikołaja Kopernika w Toruniu w 2015 r.). Obecnie adiunkt w Katedrze Historii Nowożytnej w Instytucie Historii Uniwersytetu Łódzkiego. Sekretarz redakcji „Zapisek Historycznych” i „Wiadomości Historycznych z Wiedzą o Społeczeństwie”. Kie- 
rownik organizacyjny Ogólnopolskiej Olimpiady Historycznej. Główne zainteresowania naukowe: kultura szlachecka Rzeczypospolitej Obojga Narodów, historia intelektualna i kulturowa XVIII wieku, edytorstwo źródeł historycznych i edytorstwo współczesne. E-mail: joanna.orzel@interia.eu 